\title{
Vízzáró borítás kialakítása korrózióálló acélfólia lézersugaras hegesztésével
}

\section{Fabrication of a Laser Welded Waterproof Coating Made of Stainless Steel Foil}

\author{
Acél Artúr Benjámin, ${ }^{1}$ Windisch Márk, ${ }^{2}$ Maloveczky Anna ${ }^{3}$ \\ Bay Zoltán Alkalmazott Kutatási Közhasznú Nonprofit Kft. Budapest, Magyarország, \\ 1 artur.acel@bayzoltan.hu \\ ${ }^{2}$ mark.windisch@bayzoltan.hu \\ 3 anna.maloveczky@bayzoltan.hu
}

\begin{abstract}
The purpose of this engineering design was to fabricate a waterproof coat for a carbon fibre reinforced polymer component. Austenitic stainless steel foil with $50 \mu \mathrm{m}$ thickness was used as the raw material. Deep-drawn elements that fit the geometry of the given part were welded together to form the coat. The deep drawing tools and the welding machine were self-designed and manufactured. The cutting of the blank and then the welding technology of the deep-drawn tablecloths were carried out with a TruMark 5010 marking laser made by Trumpf.
\end{abstract}

Keywords: laser welding, stainless steel, thin foil, micro-welding.

\section{Összefoglalás}

A mérnöki tervezés célja szénszálerősítésű műanyag alkatrész vízzárásának kialakítása volt. Alapanyagként $50 \mu \mathrm{m}$ vastag ausztenites rozsdamenetes acélfóliát használtunk. A borítás kialakításához, a megadott alkatrész geometriájához illeszkedő, mélyhúzott elemeket hegesztettünk össze. A mélyhúzó szerszámok és a hegesztőkészülék saját tervezésű és gyártmányú volt. A terítékek vágását, majd a mélyhúzott terítékek hegesztési technológiáját Trumpf gyártmányú TruMark 5010 típusú jelölő lézerrel valósítottuk meg.

Kulcsszavak: lézersugaras hegesztés, korrózióálló acél, vékony fólia, mikrohegesztés.

\section{Bevezetés}

Korunkban megfigyelhető tendencia az egyre kompaktabb és kisebb méretű műszerek fejlesztése, alkalmazása. Emiatt nagyobb igény van a vékony acélfóliák $(<100 \mu \mathrm{m})$ hegesztésére. Több cikk is született acélfóliák kis teljesítményü lézersugaras hegesztésének megvalósításáról. [1, 2, 3]

Vékony fóliák hegesztési eredményei alapján megoldást dolgoztunk ki szénszálerősítéses autóipari alkatrész vízzáró borítására. A szerelési követelményeket figyelembe véve $50 \mu \mathrm{m}$ vastag korrózióálló acélfóliát használtunk a vízzáró borítás kialakításához.

\section{Alkalmazott anyagok és módszerek}

A fóliák vágásához és hegesztéséhez Trumpf gyártmányú TruMark 5010 típusú lézersugaras jelölőberendezést használtunk. A lézerberendezés szilárdtest-rezonátorának impulzusideje 250 ns, átlagos teljesítménye 18,5 W, a nyaláb hullámhossza $1064 \mathrm{~nm}$, ismétlési frekvenciája vágásnál $20 \mathrm{kHz}$, hegesztésnél $100 \mathrm{kHz}$ volt.

A későbbiekben a 18,5 W átlagteljesítményt vettük alapul a hegesztési teljesítmények meghatározásánál.

A varratok keresztmetszetének metallográfiai vizsgálatához Keyence VHX 2000-es digitális opti- 
kai mikroszkópot használtunk. A varratok metallográfiai előkészítését csiszolással és polírozással végeztük, ezt követően a szövetszerkezet megjelenítése céljából királyvízzel marattuk.

\section{Technológiai lépések}

A beborítani kívánt, szénszálerősítéses műanyag alkatrész hengeres, és rajta váll van kialakítva. Az alkatrész geometriájából adódóan a borítás kialakítására kétféle lehetőség adódott. Első megoldásként $2 \mathrm{db}$ alkatrészt terveztünk. Az egyik alkatrész a hengeres rész fedele, a másik alkatrész pedig a palástot és a karimát alkotja. Ezt a két alkatrészes változatot az $50 \mu \mathrm{m}$ vastag korrózióálló fólia rossz alakváltozási tulajdonsága miatt vetettük el. A rossz alakváltozási tulajdonság miatt ugyanis alakítás során könnyen elszakad a fólia. Második megoldásként három alkatrészt terveztünk. Ebben az esetben is megtartottuk a fedő alkatrészt, viszont a palást és a váll befedésére két alkatrészt terveztünk. Az alkatrész elkészítéséhez terítékekre volt szükségünk. Ezeket a terítékeket az elkészült szerszámokkal mélyhúztuk, majd a mélyhúzott darabokat a hegesztőkészülék segítségével összehegesztettük.

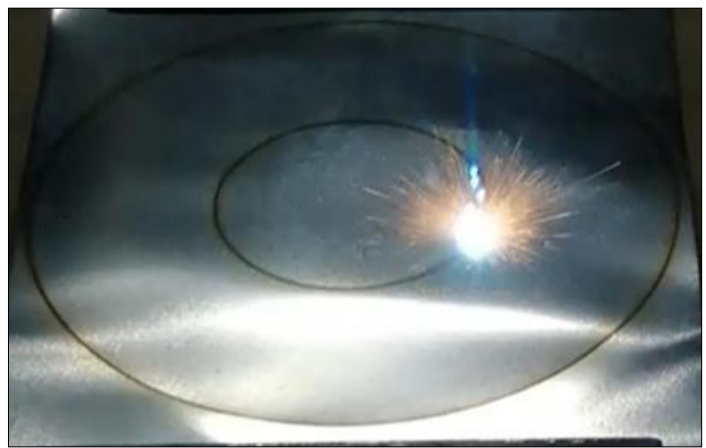

1. ábra. A terítékek vágása TruMark 5010-es berendezéssel

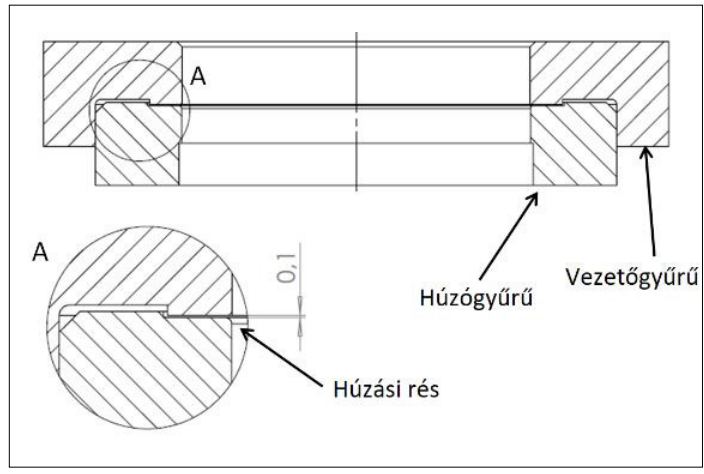

2. ábra. A mélyhúzó szerszám vázlata

\subsection{A terítékek vágása}

A terítékek vágását az alkalmazott lézersugaras berendezés Tru Tops Mark nevü programjának segítségével valósítottuk meg.

A lézersugárvágási teljesítményt 18,5 W-ban, a hegesztési sebességet $200 \mathrm{~mm} / \mathrm{s}$-ban határoztuk meg, azért, hogy a fóliát a lézersugár biztonsággal átvágja (szublimációs vágás). A lézersugaras kezelést egy mintán, azonos beállítással, egymást követően tízszer ismételtük meg.

\subsection{Mélyhúzó szerszámok}

A mélyhúzó szerszámok kialakításánál, a lemez mélyhúzás közbeni lehetséges ráncosodása miatt, a húzási rés méretét a megfelelő szorítóerő érdekében optimalizáltuk. A tárcsák központosítását egy erre a célra előkészített, $100 \mu$ m méretű vállal oldottuk meg. A húzó- és vezetőgyürűket csavarkötéssel rögzítettük egymáshoz.

A terítékekből a mélyhúzás után a következő alkatrészeket készítettük el. A 3. ábrán a mélyhúzott karima, a 4. ábrán a mélyhúzott fedél látható. Az 5. ábrán pedig már az összehegesztett palástot láthatjuk.

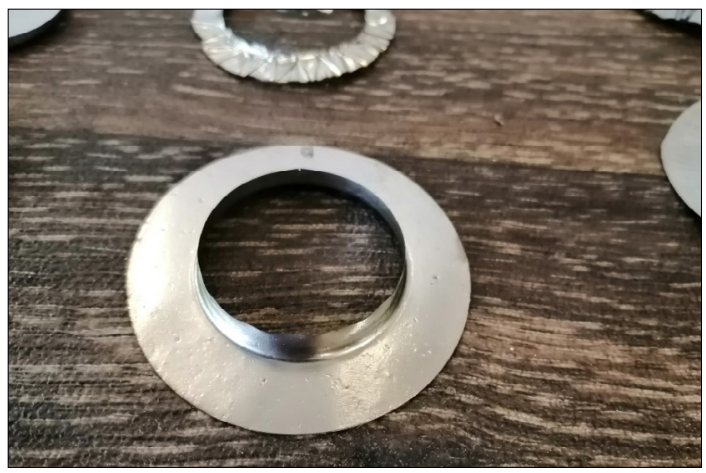

3. ábra. A sikeresen mélyhúzott karima

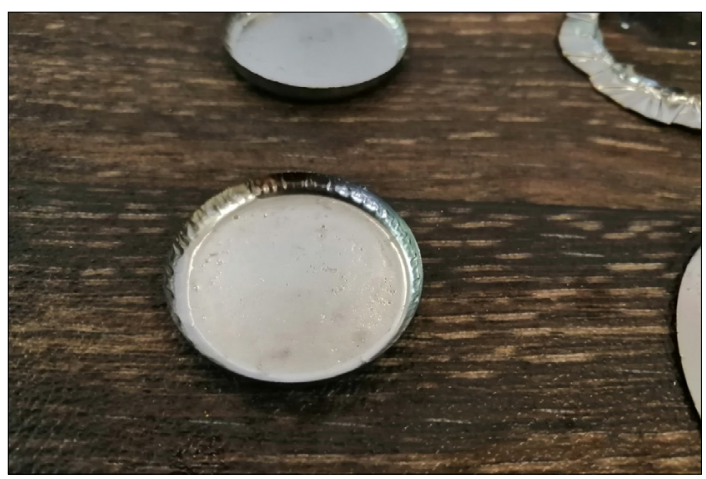

4. ábra. A sikeresen mélyhúzott fedél 


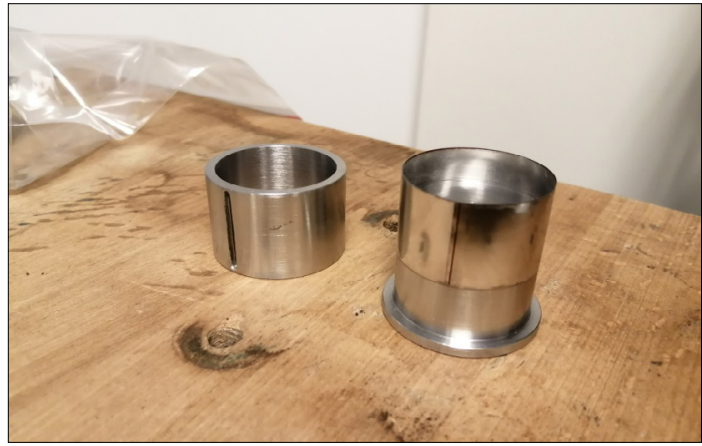

5. ábra. A sikeresen meghegesztett palást a palásthegesztő készülékkel

\subsection{Hegesztés}

$\mathrm{Az}$ alkatrészek hegesztéséhez két készüléket terveztünk. Az egyik készülék segítségével a palást varratát alakítottuk ki, míg a másikkal a kész darabot hegesztettük össze a három alkatrészből. A hegesztés során a palást varratának kialakításához a lézersugár átlagos teljesítményértékét 16,65 W-ban határoztuk meg, a hegesztési sebességet $55 \mathrm{~mm} / \mathrm{s}$-ben. A hengerpalást varratának kialakításához a lézersugár átlagos teljesítményét 17,58 W-ban, a hegesztési sebességét $55 \mathrm{~mm} / \mathrm{s}$ ben határoztuk meg. A 6. ábrán a kész alkatrész hegesztése látható.

\subsection{A varratok bemutatása}

A mélyvarratos lézersugaras hegesztéshez általában úgynevezett folyamatos üzemű lézersugárra van szükség. A mi esetünkben a lézersugaras berendezés impulzusos üzemű volt. Annak érdekében, hogy a lézersugár minél inkább a folyamatos üzemű kicsatolásra hasonlítson, a lehető legnagyobb, $100 \mathrm{kHz}$-es impulzus üzemmódot alkalmaztuk. A kísérletsorozatban a hegesztési sebességet és a lézersugár átlagos teljesítményét optimalizáltuk.

Az impulzus üzemű lézersugár átlagos teljesítményének optimumát $16,65 \mathrm{~W}$ és $17,58 \mathrm{~W}$ közöttinek találtuk. A hegesztési sebesség értékét $55 \mathrm{~mm} / \mathrm{s}$ nagyságúnak választottuk. A 7. ábrán a 16,65 W-os átlagteljesítményü lézersugárral hegesztett varrat geometriáját láthatjuk. A koronaoldalon megjelenő anyaghiány a varrat funkciója szempontjából nem releváns. Az átlapolt vékony fóliákat teljes vastagságukban átolvasztotta a lézersugár. A 17,58 W teljesítménnyel elkészített varrat keresztmetszeti alakját a 8. ábrán figyelhetjük meg. Ebben az esetben a koronaoldalhoz hasonlóan a gyökoldalon is megjelenik az anyaghiány. A fóliák teljes vastagságát tekintve az anyag átolvadt.

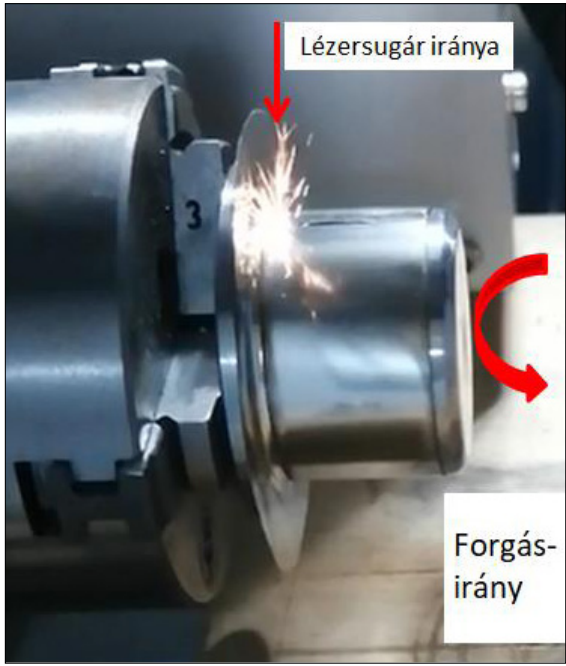

6. ábra. A palást és a karima körvarratos hegesztése

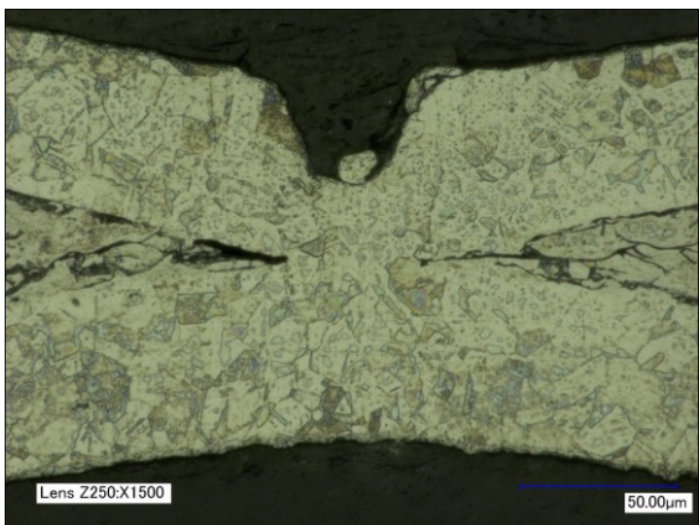

7. ábra. A 16,65 W átlagteljesítményü lézersugárral, $55 \mathrm{~mm} / \mathrm{s}$ hegesztési sebességgel létrehozott varrat metszeti metallográfiai képe

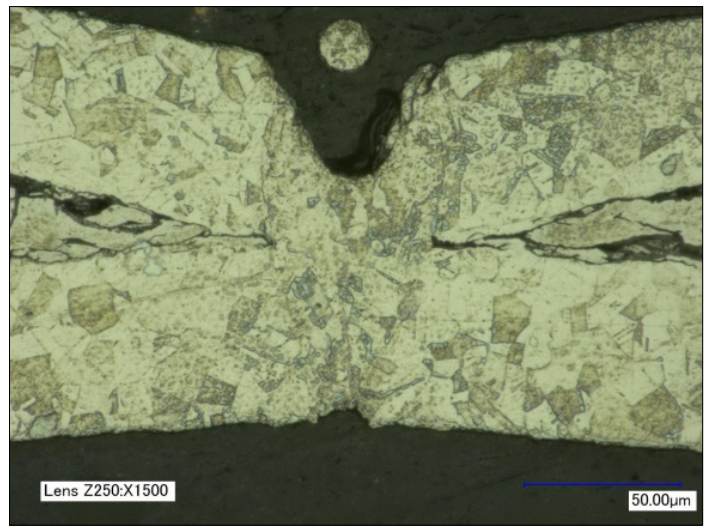

8. ábra. A 17,58 W átlagteljesítményü lézersugárral, $55 \mathrm{~mm} / \mathrm{s}$ hegesztési sebességgel létrehozott varrat metszeti metallográfiai képe 


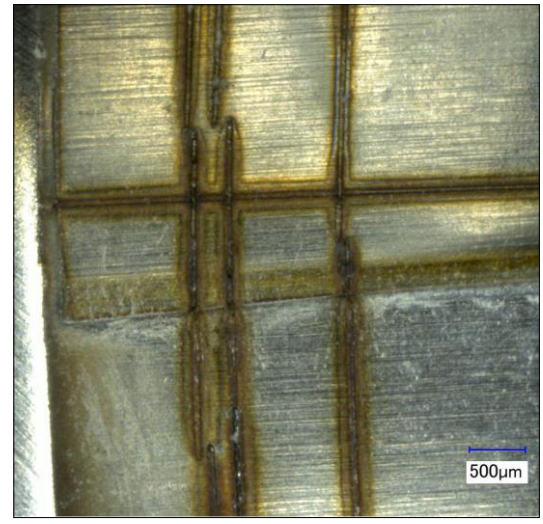

9. ábra. Hegesztési varratok a palást és a karima átfedési helyén

\section{5. Értékelés}

Trumpf TruMark 5010 típusú lézerberendezéssel sikerült $50 \mu \mathrm{m}$ vastag korrózióálló acélfóliából meghatározott geometriájú terítékeket kivágni. Ezeket a terítékeket saját tervezésű mélyhúzó szerszámmal alakítottuk. A mélyhúzott részeket sikeresen egymáshoz hegesztettük. Az elkészült alkatrész a 10. ábrán látható.

Az elkészített alkatrészek víztömörség-vizsgálata folyamatban van. Jövőben a vizsgálati terv része a varratok átlapolásának növelése a Trumpf TruMark 5010-es berendezésen. A technológia továbbfejlesztésének korlátja a lézersugár-kicsatolás és a CNC-forgató tengely szinkronvezérlésének hiánya.

\section{Köszönetnyilvánítás}

A kutatás az Európai Unió és a Magyar Kormány támogatásával, az Európai Regionális Fejlesztési Alap társfinanszírozásával valósult meg az „E-mobility

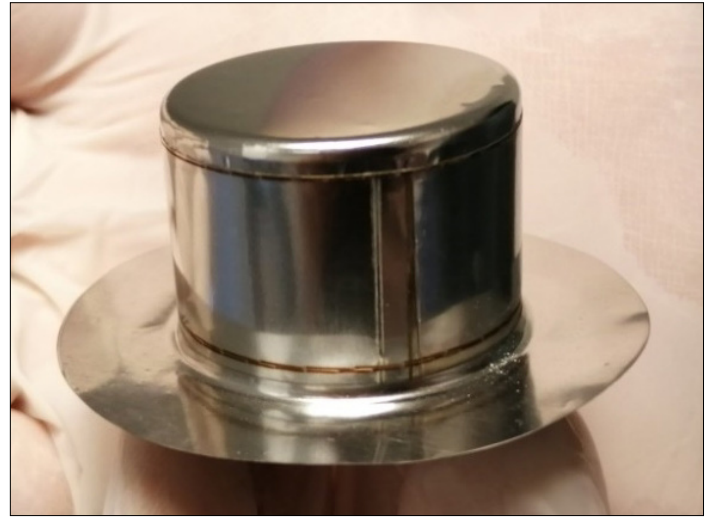

10. ábra. A három varrattal elkészült vízzáró borítás

Miskolcról: Hűtővíz keringető szivattyú és motorhűtő ventilátor továbbfejlesztése az elektromos járművekben elvárt magasabb minőségi követelmények figyelembevételével” című, GINOP-2.2.1-15-2017-00090 azonosítószámú projekt keretében.

\section{Szakirodalmi hivatkozások}

[1] Pakmanesh M. R., Shamanian M.: Optimization of pulsed laser welding process parameters in order attain minimum underfill and undercut defects in thin 316L stainless steel foils. Optics and Laser Technology, 99. (2018) 30-38. https://doi.org/10.1016/j.optlastec.2017.09.047

[2] Abe N., Funada Y., Imanaka T., Tsukamoto M.: Micro welding of thin stainless steel foil with a direct dioda laser. Transactions of JWRI, 34/1. (2005).

[3] Ventrellaa V. A., Berrettab J. R., Rossib W.: Pulsed Nd:YAG laser seam welding of AISI 316L stainless steel thin foils. Journal of Materials Processing Technology, 210/14. (2010) 1838-1843. https://doi.org/10.1016/j.jmatprotec.2010.06.015 